\title{
Umbilical Cord Blood Banking: Current \& Future Status
}

\author{
Dr. Kinara Patel ${ }^{1}$, Dr. Himani Patel ${ }^{2}$
}

\begin{abstract}
Umbilical cord blood (UCB) has been shown to be a suitable source of haematopoietic stem cells (HSCs) for haematopoietic reconstitution. An increase in the number of UCB transplants indicates an expansion of utility in a broad spectrum of disease conditions. Along with the advantages, UCB also has limitations, and hence several investigators are working to further optimize UCB for this use. Beyond haematopoietic transplantation, additional potential applications of UCB include immunotherapy, tissue engineering and regenerative medicine. UCB banking has improved with time largely due to involvement of professional organizations and their published standards. However, accreditation of these organizations remains voluntary, and in India three of ten banks are public with the remaining being private. Only one public and one private bank are American Association of Blood Banks (AABB) accredited in India. Government agencies need to provide regulatory and safety oversight, which is lacking in serveral countries. Public policy regarding $U C B$ is in its infancy throughout most of the world. Ethical issues, including access to UCB banking and use as therapy for diseases other than haematological and metabolic disorders are in the early phase of trials and remain speculative.
\end{abstract}

Keywords: Haematopoietic reconstitution - stem cells - umbilical cord blood (UCB)

\section{Introduction}

Stem cell based therapies are increasingly being utilized with promising results in both malignant and non-malignant disorders $^{1-3}$. Three sources of cells have been used for haematopoietic reconstitution - bone marrow (BM), peripheral blood (PB), and umbilical cord blood (UCB) $)^{3-5}$. $\mathrm{UCB}$, the most recently identified source of stem cells, appears to be as effective as bone marrow when an HLAmatched adult donor is not available ${ }^{6,7}$. In the past decade, the clinical applications of UCB-based cell therapies have broadened with a growing number of diseases treated with haematopoietic stem cell (HSC) transplantation. Additionally, several investigational human trials involving cell types derived from UCB have been initiated ${ }^{4,6,7}$. As the clinical utility has become apparent, collection and banking of UCB have become more widespread all over the world ${ }^{8}$. The expansion of UCB banking has led to the establishment of UCB quality standards by professional groups such as AABB (formerly known as American Association of Blood Banks) and the Foundation for Accreditation of Cellular Therapy (FACT)/NETCORD ${ }^{9,10}$. These best-practice expectations pertain to collection, testing, processing and banking of UCB for transplantation ${ }^{11}$. There are at least 142 public [three in India - Relicord (Reliance Life Science), (Jeevan Cord and Stemcyte) and 25 private (seven in India) UCB banks worldwide ${ }^{12,13}$ with several more likely to open in the near future. While standards appropriately cover UCB banking, guidelines regarding other issues including those with ethical implications (e.g., patient access, clinical applications) are lacking in particular for autologous UCB transplantation. In India and other countries private UCB banking dominates, limiting general public access to promising therapies. Further, worldwide, clinical trials for a variety of diseases are ongoing despite inadequate preclinical studies and regulatory/safety oversight.

\section{The success of UCB transplantation in the world}

While bone marrow and peripheral blood stem cell transplants have a proven track record of success, the search process can take several months. Despite almost 13 million registered volunteer donors are presently accessible worldwide, many patients do not get HLA matched grafts. Hence, the applicability of HSC transplantation has markedly expanded with the introduction of UCB, especially for ethnic and racial minorities. Therefore, UCB has gained popularity and acceptability as an alternative transplant source for patients lacking appropriate adult donors. In a report of 623 consecutive patients undergoing myeloablative transplant at the University of Minnesota, Tomblyn and colleagues $^{14}$ have shown that ALL (acute lymphoblastic leukemia) patient lacking a sibling donor can seek UCB or a well-matched unrelated donor and have equivalent long-term survival. After a median of 8.3 years of follow up, five year overall survival, leukemia free survival (LFS) and relapse were 29, 26 and 43 per cent respectively. Five year LFS was 40,42 and 49 per cent with related donors (RD), well matched unrelated donors (URD) and UCB sources, respectively, while relapse was 31,17 and 27 per cent in the same group. Several additional studies support satisfactory results of UCB transplant as compared to other sources of haematopoietic stem cells ${ }^{15,16}$. In addition to paediatric and adult haematological malignancies, UCB has potential applications in non-malignant and metabolic disorders ${ }^{17}$. Due to the decreased risk of graft versus host diseases (GVHD) the use of UCB transplant over related BMT in thalassaemia $^{18,19}$. In cases of Fanconi anemia, Gluckman et $a l^{20}$ have demonstrated significantly improved engraftment (89 vs 69\%) and survival (52 vs. 13\%) in those received fludarabine versus no fludarabine.

In metabolic storage disorders the only therapeutic option is enzyme replacement therapy which is expensive with a longterm requirement. Hence, UCB transplant is desirable and a promising alternative therapeutic option with long term benefits. Prasad et $a l^{21}$ have reported results of 159 paediatic patients with inherited metabolic disorders who received UCB transplant. Engraftment occurred in 87.1 per cent and one year overall survival was 71.8 per cent. Notably those children with high performance status had better overall survival of nearly 85 per cent which emphasizes the importance of UCB transplant early in the course of the disease. 


\section{International Journal of Science and Research (IJSR) \\ ISSN (Online): 2319-7064}

Index Copernicus Value (2013): 6.14 | Impact Factor (2014): 5.611

Most UCB banks in India have been opened in the last few years, and UCB transplantation is in its infancy, very few reports are available for application to acquired and constitutional haematological disorders and none for metabolic disorders. Till date approximately 32 patients have been transplanted using related or unrelated UCB. Of these 2 patients of relapsed leukemia were transplanted using mismatched sibling cord [UCB processed at Life cell and Cryo Bank] and one died of disease relapse and other of sepsis. One child was transplanted using fresh fully matched cord and the child is well 12 years on and did not go through any cord bank. In 15 patients mainly for relapsed leukemia and aplastic anemia unrelated cord blood was used with TRM of 55 per cent at Apollo, Chennai. While one patient of leukemia transplanted at Gujarat Cancer \& Research Institute (GCRI), Ahmedabad expired due to disease related mortality after transplantation. The high mortality rate appears to be due to selection of high risk cases under this group.

To date, around 13 cases of thalassaemia have been treated using UCB transplantation. Of these, six cases were transplanted using fully matched sibling UCB at Apollo hospitals, Chennai. UCB units were obtained from Life Cell and Cord bank. Thalassemia free survival was 83 per cent and all patients had additional bone marrow from siblings as there was inadequate cell dose in cord blood. Similarly, seven unrelated UCB units were utilized to treat thalassaemia cases at GCRI, Ahmedabad. The unrelated UCB units were procured from Relicord and Stemcyte UCB banks. TRM was 0 per cent at both the centers. At GCRI, Ahmedabad, two thalassaemia patients had disease free survival after 2 years and 1 year of transplantation, and one remained hospitalized post-transplantation. Failure of engraftment was observed in four cases which is likely to be due to low number of total nucleated cell (TNC) $\left(2-3 \times 10^{7}\right)$ used in transplantation. Considering large number of thalassaemia patients born in the country; these transplantations are comparatively very less mainly because of cost prohibition, lack of sufficient UCB depository and because public UCB banks are in early stage of development. In the coming years with an increased transplantation using $\mathrm{UCB}$ as a source of haematopoietic stem cells, more experience will undoubtedly be gained ${ }^{22}$.

\section{Difference between related and unrelated transplants}

The vast majority of UCB transplants are from unrelated donors. Despite the fact that related UCB transplant was largely replaced by unrelated donor transplant, the former source of stem cells still remains a reality in a minority with not having access to suitable donors ${ }^{23}$. In this era of public and private UCB banking for storing and freezing UCB units, related UCB transplant may regain priority. The EUROCORD group reported the results of related UCB transplant in 44 children with haemoglobinopathies (thalassaemia in 33 and sickle cell anaemia in 11) who received fully matched UCB grafts with only 3 children receiving 1 locus mismatched grafts ${ }^{18}$. In their series donor type reconstitution of hematopoiesis was obtained in 86.4 per cent of transplants with median times to neutrophil and platelet engraftments at 23 and 39 days, respectively with overall disease free survival of 79 and 90 per cent in thalassaemia and sickle cell anaemia respectively. GVHD was limited in 2 of 36 patients with no transplant related mortality receiving related UCB transplantation.

In recent years with growing demand of transplantation, unrelated UCBT (UD-UCBT) has become an alternative transplant method for patients lacking a suitable donor. In a study nine autologous and 41 allogenic transplants were carried out using privately banked $\mathrm{UCB}^{24}$. The study demonstrated that 36 of 41 allogenic cases were due to known indication of haematological malignancy while those with autologous mainly included neuroblastoma, retinoblastoma, Shwachman Diamond syndrome, brain tumour and severe aplastic anaemia. The study indicates that very few would choose autologous UCB over alternative stem cell source for ALL in second remission. In contrast, 55 per cent would choose autologous cord blood to treat high risk cases or severe aplastic anaemia in the absence of an available sibling donor. In another study, the outcome of HCT was similar for transplantation using RD, well matched URD, partial matched URD or UCB sources in patients with ALL. It was further stated that autologous HCT should no longer be used for high risk or relapsed ALL due to the unacceptably high relapse and poor long term survival. The study concluded that patients with ALL lacking a sibling donor can seek well matched UCB for best overall and LFS or well matched URD with a long term good chances of LFS.

\section{Genesis of UCB banks in the world}

UCB has been shown to be a viable alternative to BM and PB. Further, UCB has clear advantages over the other sources of stem cells. It requires less restrictions for matching, as the naïve immune system appears to cause less severe GVHD. Perhaps most importantly, UCB is HLA typed and banked allowing for listing on a registry for rapid search and acquisition ${ }^{25}$.

Since the first successful transplant in a child with Fanconi anaemia in 1988, UCB has emerged as a feasible alternative source of haematopoietic progenitor/stem cells for allogenic transplantation $^{26}$. To date, more than 10,000 patients worldwide have received an UCB transplant. Public UCB banks are growing in support of the increase in utilization of this newest graft source with recent reports indicating that there are greater than 450,000 unrelated units banked worldwide for potential clinical use $\mathrm{e}^{13,27}$.

The first unrelated UCB bank was started at the New York Blood Center in 1992. There are now nearly 142 public banks and at least an additional 25 private banks actively involved around the world in collecting, processing, testing (e.g., HLA typing, infectious disease testing), and cryopreserving UCB for potential future use as therapeutics $^{13,28}$. The highest inventory of $48,808 \mathrm{UCB}$ is with New York Blood Center's National Cord Blood Program. This type of program in general is funded in part or entirely by public funds. These banks are typically "notfor-profit" with their primary purpose being creation of an inventory of UCB units for unrelated use. UCB is donated to the bank, and the units are made available to suitably matched recipients regionally, nationally or internationally. 


\section{International Journal of Science and Research (IJSR) \\ ISSN (Online): 2319-7064}

Index Copernicus Value (2013): 6.14 | Impact Factor (2014): 5.611

The alternative approach involves "for- profit" companies which encourage parents to bank their child's UCB for their own (autologous) or a family member's (related, allogeneic) use should a need arise. For a fee, the UCB is processed and stored as a form of "biological insurance".

\section{Genesis of UCB banks in India and UCB banking organization in the Indian context}

With India's booming birth rate of 26 million births per year $^{30}$ and genetic diversity; the country would be poised to be the largest collector of UCB in the world. Three public banks are established in India

Relicord, Jeevan Cord and Stemcyte, collectively having 10,000 plus units. Similarly, seven private banks have been established to date. These are Life Cell with maximum inventory of 19,000 plus followed by Cryo Banks having 17,000 plus samples and about 4,500 between Cryosave, Cord Life, Baby Cell, Stem One and ISSL (International Stem Cell Service). Four of these are certified by ISO whereas Life cell and Relicord are accredited by AABB. Most of these are affiliated with or are subsidiaries of international companies.

The major problem faced in India is collection of UCB due to high cost and comparatively less functional public banks. In addition, considering a large population with deliveries in public hospital due to low cost, UCB storage in India needs increased public-private partnership model where UCB can be stored by affordable and non-affordable people as well.

\section{Progress of UCB banking for family use and its significance}

Families may choose to store UCB in a bank for prophylactic or pre-emptive reasons. When banked preemptively, a family member is known to have or to be at increased risk for a potentially transplantable disease. In the promotional material, private UCB banks indicate that stored UCB may serve as a source of stem cell for autologous or allogenic haematopoietic stem cell transplantation and that these cells may be modified through gene transfer or targeted differentiation for treating degenerative disorders like Alzheimer disease, Parkinson disease and ischaemic heart disease ${ }^{28}$. In fact, at best in some cases, efficacy is speculative and may not even be under trial currently ${ }^{31}$. There are only a few reports that demonstrate the use of privately stored cord blood for autologous transplantation in leukemia and severe aplastic anaemia ${ }^{28}$.

Unlike private UCB banks, public banks are not aggressive with their marketing. Another important issue is access to the UCB stored in a public bank. After donation, the unit belongs to the bank; however, most banks will return a UCB unit to a family should it be needed and, of course, if it is still in the inventory at the time of request. In essence, a family donating a unit to a public bank does have a degree of a "biological insurance" as well. Alternatively, many private banks assure storage and accessibility for 15-20 yr. It appears that many Indian citizens opt for private UCB banking. The shelf-life or stability of UCB is uncertain ${ }^{8}$ although there is evidence of efficacy in the range of 15-18 yr.

There may be a degree of variance from unit to unit or bank to bank. Thus, it cannot be assumed that all units stored for a particular period of time will be equally potent and efficacious. More studies are necessary, and it is likely that each bank will need to establish stability within their own institution using their own units.

\section{Regulatory environment in India and other countries}

At present, the role that any government should play in UCB banking remains unclear. However, in developed and developing countries with a universally accessible healthcare system, public policy makers will soon be confronted with the difficult task of deliberating the merits and economics of establishing a national network of public UCB banks, including the value of private banking of UCB for autologous/family use. A policy framework may be necessary to guide this decision-making.

The Guidelines from the Indian Council of Medical Research (ICMR) and Department of Biotechnology (DBT) are available to assist with stem cell research and UCB issues ${ }^{33}$. Additionally, the aforementioned standards (AABB, FACT/NETCORD) could facilitate the effort to establish public UCB banks throughout India. Roughly 0.25 per cent of the global shares of UCB transplants are done in India, and only three ICMR licensed UCB banks are operational in the country ${ }^{22,34}$

The field of UCB stem cell therapy is still gaining experience in India, and there are many regulatory and policy issues pertaining to the allogenic transplantation for inherited disorders and transmissible infectious diseases that are yet to be addressed in addition to the draft guidelines by ICMR and DBT. There are unique ethical issues related to private UCB banking, and policymakers cannot chart the future of UCB banking in the country without taking into account the existence of private banks and their potential role in meeting future clinical needs, as well as their actual and potential contribution to research in this domain. Now is the time to prospectively address the socio-ethical and legal issues surrounding UCB banking and uses.

Several organizations have taken the position that UCB banking for autologous use should be discouraged. The Society of Obstetricians and Gynecologists of Canada Clinical Practice Guidelines ${ }^{32}$ and American Academy of Pediatrics ${ }^{8}$ clearly state that collection and long-term storage of UCB for autologous donation is not recommended because of the limited indications and lack of scientific evidence to support the practice. The clinical utility of autologous UCB storage is said to be limited because of the very low probability that an autologous haematopoietic stem cell transplant will be required by the individual in his/her lifetime, the uncertain shelf-life of stored UCB, and the fact that autologous transplants are not recommended for inherited disorders or blood cancers ${ }^{12}$. UCB education is also supported by legislation at the federal and State levels in USA. The Institute of Medicine (IoM) report "Establishing a National Cord Blood Stem Cell Bank Program" 


\section{International Journal of Science and Research (IJSR) \\ ISSN (Online): 2319-7064}

Index Copernicus Value (2013): 6.14 | Impact Factor (2014): 5.611

recommends that expectant parents be given a balanced perspective on their options for cord blood banking for donating, discarding or banking life saving newborn stem cells $^{35}$.

\section{Possible applications of UCB for regenerative medicine application}

Regenerative medicine is a field of medical research developing treatments to repair or re-grow specific tissue in the body. UCB cells are an attractive choice for tissue engineering and regenerative medicine, as these have shown promise for numerous disease states. The identification of one cell type in UCB, mesenchymal stem cells (MSCs), heralds UCB as an untapped resource for nonhaematopoietic stem cell-based therapeutic strategies for the replacement of injured or diseased connective tissue ${ }^{37}$. UCBderived endothelial progenitor cells (EPCs) are another logical cell type for use in tissue engineering and regenerative medicine. Janic et $a l^{38}$ demonstrated that UCBderived AC133+ cells were primarily EPCs capable of maintenance of endothelial lineage in long-term culture. A recent study by $\mathrm{Li}$ et $a l^{39}$ successfully used microencapsulated UCB cells for liver injury in mice. This represents a future possible alternative to liver transplantation. The use of UCB stem cells in treating brain injury and type I diabetes is already being studied in humans and earlier stage of research is being conducted for stroke and hearing loss ${ }^{40-43}$.

The potential for the use of UCB stem cells to regenerate insulin production in juvenile diabetes patients has been reported $^{38}$. These children are now pioneers in helping to develop effective therapies for juvenile diabetes using one's own stem cells. This option is only available to those whose parents made the decision to preserve their $\mathrm{UCB}^{41}$.

In a meeting of the International Society for Stem Cell Research in 2007, the potential for UCB stem cells to improve outcomes in human patients following heart attack was presented by Dr Harris. The data showed that in an animal model of heart attack, intracoronary delivery of cord blood stem cells increased the vascular density in the heart compared to untreated animals ${ }^{44}$.

Research in animal models have shown that UCB stem cells injected intravenously have the ability to migrate to the area of brain injury alleviating mobility related symptoms. Further, injecting human UCB stem cells into animals with stroke was shown to significantly improve behaviour by stimulating the new blood vessels formation and neurons in the brain ${ }^{45}$. Vision loss can occur when corneal epithelial cells are lost or are not replaced quickly. Scientists have demonstrated that UCB stem cells can differentiate into the cells that are indistinguishable from corneal epithelial cells. When transplanted in animals, UCB stem cells improved the appearance of the corneal surface suggesting that UCB could provide a future therapeutic option for ocular surface disorder ${ }^{46}$.

All these studies indicate that children whose UCB stem cells are available for their own potential use could be among the first one to benefit from the newer research in
UCB transplantation without having the risk of rejection by the immune system.

\section{Novel approaches of UCB transplantation}

For older patients and those with co-morbidities in addition to malignancy and extensive pre-transplant treatment, reduced intensity conditioning transplants reduced intensity conditioning (RIC) may achieve the same goals as with myeloablative conditioning but with less toxicity. Brunstein et $a l^{47}$ reported results in 110 adults transplanted with UCB for haematological diseases with 92 per cent sustained engraftment, 19 per cent TRM and three year overall survival (OS) of 45 per cent which is similar to those with other stem cell sources. This study thus extends the availability of transplantation therapy to the elderly excluded on the basis of age and lack of a suitable matched donor and those with co-morbid conditions.

\section{Expansion of UCB stem cells}

UCB can be expanded ex vivo over 400 -fold by culture techniques that can block cell differentiation with elimination of certain components like copper. Peled et $a l^{48}$ indicate that $3 \mathrm{wk}$ treatment with a copper chelator results in preferential proliferation of a subset of CD34+ cells which seem to be responsible for expansion in long term culture. Recently Deutsch et $a l^{49}$ demonstrated a novel approach to UCB stem and progenitor cell expansion through haematopoietic niche mimicry using fibronectin and acetylcholine esterase read-through peptide (ARP). The work by Delaney et $a l^{50}$. is most promising as it is the first example of rapid engraftment of ex vivo expanded UCB in humans with a median time to neutrophil engraftment of 16 days (range 7-34). This study is now moving to phase II (efficacy) trials in the USA, and the results are highly anticipated. Several additional studies involving unique approaches to UCB expansion are underway in the research laboratories and early clinical trials setting ${ }^{38}$.

\section{Conclusion}

India has great potential for UCB banking due to a high birth rate and genetic diversity. Nearly 70 per cent of patients of Indian origin who require bone marrow transplantation do not find a match within their own family. Hence, unrelated UCB is a widely accepted source of progenitors for hematopoietic stem cell transplantation. However, to-date the total number of UCB transplants performed in India has been very low mainly due to high cost and limited number of UCB units available against the estimated requirement of 30,000 units. But with the existence of three public UCB banks these figures are likely to improve in the coming years. This will offer a diverse source of high quality grafts for patients of Indian origin worldwide. Private banks continue to grow in India, as many families opt to store UCB in private banks with possible advantages in degenerative disorders in the future. To meet the future transplantation needs of the country, full participation and substantial investment by the Government is necessary. Establishing a foundation, including infrastructure (facilities, technical and quality assurance expertise, etc.) will support an UCB programme which will be representative for all regions of the country. 


\section{International Journal of Science and Research (IJSR) \\ ISSN (Online): 2319-7064}

Index Copernicus Value (2013): 6.14 | Impact Factor (2014): 5.611

\section{References}

[1] Cohen Y, Nagler A. Umbilical cord blood transplantation - how, when and for whom? Blood Rev 2004; $18: 167-79$.

[2] Martin PL, Carter SL, Kernan NA, Sahdev I, Wall D, Pietryga D, et al. Results of the cord blood transplantation study (COBLT): outcomes of unrelated donor umbilical cord blood transplantation in pediatric patients with lysosomal and peroxisomal storage diseases. Biol Blood Marrow Transplant 2006; 12 : 18494.

[3] Rocha V, Labopin M, Sanz G, Arcese W, Schwerdtfeger R, Bosi A, et al. Transplants of umbilical cord blood or bone marrow from unrelated donors in adults with acute leukemia. N Engl J Med 2004; 351 : 2276-85.

[4] Bensinger WI, Clift R, Martin P, Appelbaum FR, Demirer T, Gooley T, et al. Allogeneic peripheral blood stem cell transplantation in patients with advanced hematologic malignancies: a retrospective comparison with marrow transplantation. Blood 1996; 88 : 2794800.

[5] Cohen Y, Nagler A. cord blood biology \& transplantation. Isr Med Assoc J 2004; 6 : 39-46.

[6] Cohen Y, Nagler A. Hematopoietic stem-cell transplantation using umbilical cord blood. Leuk Lymphoma 2003; 44 : 1287-99.

[7] Lusin BH, Shearer WT. American Academy of Pediatrics section on Hematology/Oncology; American Academy of Pediatrics section on Allergy/immunology. Cord blood banking for potential future transplantation. Pediatrics 2007; 119 : 165-70.

[8] McCullough J, McKenna D, Kadidlo D, Schierman T, Wagner J. Issues in the quality of umbilical cord blood stem cells for transplantation. Transfusion 2005; 45 : 832-41

[9] American Association of Blood Banks. Standards for cellular therapy product services, $2^{\text {nd }}$ ed. Bethesda MD: American Association of Blood Banks; 2007.

[10] Net Cord Foundation for the Accreditation of Cellular Therapy. International standards for cord blood collection, processing, testing, banking, selection and release. $3^{\text {rd }}$ ed. Bethesda, MD: American Association of Blood Banks; 2006.

[11] Steinbrook R. The cord-blood bank controversies. $N$ Engl J Med 2004; 351 : 2255-7.

[12] World Marrow Donor Association. Stem cell registries annual report, $10^{\text {th }}$ ed. Leiden: World Marrow Donor Association; 2007.

[13] http://www.worldmarrow.org/fileadmin/WorkingGroup $\mathrm{s}$

Subcommittees/Cord_Blood_Working_Group/Cord_B1 ood_Banks_Worldwide_13042010.pdf, accessed on September 12, 2010.

[14] Tomblyn MB, Arora M, Baker KS, Blazar BR, Brunstein CG, Burns LJ, et al. Myeloablative hematopoietic cell transplantation for acute lymphoblastic leukemia: analysis of graft sources and long-term outcome. J Clin Oncol 2009; 27 : 3634-41.

[15]Ponce D, Zheng J, Gonzales AM, Castro-Malaspina HR, Hsu KC, Jakubowski A, et al. Disease-free survival after cord blood (CB) transplantation is not different to that after related or unrelated donor transplantation in patients with hematologic malignancies. 51 $1^{\text {st }} \mathrm{ASH}$ Annual Meeting and Exposition - On Line Programme and Abstracts. 2009; Abstract no. 2296.

[16] Gutman JA, Leisenring W, Appelbaum FR, Woolfrey AE, Delaney C. Low relapse without excessive transplant-related mortality following myeloablative cord blood transplantation for acute leukemia in complete remission: a matched cohort analysis. Biol Blood Marrow Transplant 2009; 15 : 1122-9.

[17] Harris DT. Non-haematological user of cord blood stem cells. Br J Haematol 2009; 147 : 177-84.

[18]Locatelli F, Rocha V, Reed W, Bernaudin F, Ertem M, Grafakos S, et al. Eurocord Transplant Group. Related umbilical cord blood transplantation in patients with thalassemia and sickle cell disease. Blood 2003; 101 : 2137-43.

[19] Jaing TH, Hung IJ, Yang CP, Tsai MH, Lee WI, Sun CF. Second transplant with two unrelated cord blood units for early graft failure after cord blood transplantation for thalassemia. Pediatr Transplant 2009; $13: 766-8$.

[20] Gluckman E, Rocha V, Ionescu I, Bierings M, Harris R, Wagner $\mathrm{J}$, et al. Results of unrelated cord blood transplant in Fanconi Anemia patients: Risk factor analysis for engraftment and survival. Biol Blood Marrow Transplant 2007; 13 : 1073-82.

[21] Prasad VK, Mendizabal A, Parikh SH, Szabolcs P, Driscoll TA, Page K, et al. Unrelated donor umbilical cord blood transplantation for inherited metabolic disorders in 159 pediatric patients from a single center: influence of cellular composition of the graft on transplantation outcomes. Blood. 2008; 112 : 2979-89.

[22] Umbilical cord blood. Available from: http://parents guidecordblood.org/content/usa/banklists/summary.sht ml\# india last modified on $13^{\text {th }}$ Sept. 2010 accessed on September 14, 2010.

[23] Barker JN. Umbilical Cord Blood (UCB) transplantation: an alternative to the use of unrelated volunteer donors? Hematology Am Soc Hematol Educ Program 2007; 55-61.

[24] Thornley I, Eapen M, Sung L, Lee SJ, Davies SM, Joffe S. Private cord blood banking: Experiences and views of pediatric hematopoietic cell transplantation physicians. Pediatrics 2009; 123 : 1011-7.

[25] Barker JN, Krepski TP, DeFor TE, Davies SM, Wagner JE, Weisdorf DJ. Searching for unrelated donor hematopoietic stem cells: availability and speed of umbilical cord blood versus bone marrow. Biol Blood Marrow Transplant 2002; 8 : 257-60.

[26] Gluckman E, Broxmeyer HA, Auerbach AD, Friedman HS, Douglas GW, Devergie A, et al. Hematopoietic reconstitution in a patient with Fanconi's anemia by means of umbilical-cord blood from HLA-identical sibling. N Engl J Med 1989; 321 : 1174-8.

[27]Sacchi N, Costeas P, Hartwell L, Hurley CK, Raffoux C, Rosenmayr A, et al; Quality Assurance and Clinical Working Groups of the World Marrow Donor Association. Hematopoietic stem cell donor registries: World Marrow Donor Association recommendations for evaluation of donor health. Bone Marrow Transplant 2008; $42: 9-14$.

[28] Cord blood Registry. Why you should save cord blood 


\section{International Journal of Science and Research (IJSR) \\ ISSN (Online): 2319-7064}

Index Copernicus Value (2013): 6.14 | Impact Factor (2014): 5.611

for your family. Available from:

http://www.cordblood.com/

cord_blood_banking_with_cbr/banking/diseases_treate d. asp?fbid=BlyS_OAIG4n, accessed on April 13, 2010. [No authors listed]. Private cord blood banks. Med Lett Drugs Ther 2004; $46: 21-2$.

[29] http://www.savethechildren.in/87-news-releases/130child-mortality-in-india.html, accessed on August 18, 2011.

[30] Viacord. Using stem cells to potentially treat heart disease. Available from: www.viacord.com/stem-cellsheart-disease. htm, accessed on September 14, 2010.

[31] Armson BA; Maternal Fetal Medicine Committee, Society of Obstetricians and Gynecologists of Canada. Umbilical cord blood banking: implications for perinatal care providers. J Obstet Gynaecol Can 2005; $27: 263-90$.

[32] ICMR-DBT guidelines for stem cell Research \& Therapy. 2006; http://medind.nic.in/iby/t06/i9/ibyt06i9p371.pdf, accessed on September 14, 2010.

[33] http://www.parentsguidecordblood.org/content/usa/ban klists/ regulations.shtml?navid=31\#india last updated. April 23 2010, accessed on September 14, 2010.

[34] http://www.iom.edu/en/Activities/Research/Cordblood Bank. aspx, accessed on November 22, 2010.

[35] Opinion No

http://ec.europa.eu/european_group_ethics/ docs/avis19_en.pdf, European Union group on ethics, accessed on November 22, 2010.

[36] Cetrulo CL. Cord-blood mesenchymal stem cells and tissue engineering. Stem Cell Rev 2006; 2 : 163-8.

[37] Janic B, Guo AM, Iskander AS, Varma NR, Scicli AG, Arbab AS. Human cord blood derived AC133+ progenitor cells preserve endothelial progenitor characteristics after long term in vitro expansion. PLoS One 2010; 5 : e9173.

[38] Li S, Sun Z, Lv G, Guo X, Zhang Y, Yu W, et al. Microencapsulated UCB cells repair of hepatic injury by intraperitoneal transplantation. Cytotherapy 2009; 11 : 1032-40.

[39] Cord Blood for Neonatal Hypoxic-Ischemic Encephalopathy, Autologous Cord Blood Cells for Hypoxic Ischemic Encephalopathy Study 1. Phase I Study of Feasibility and Safety http://clinicaltrials.gov/ct2/show/NCT00593242, accessed on August 18, 2011.

[40]Haller MJ, Viener HL, Wasserfall C, Brusko T, Atkinson MA, Schatz DA. Autologous umbilical cord blood infusion for type diabetes. Exp Hematol 2008; 36 : 710-5.

[41] Vendrame M, Gemma C, Pennypacker KR, Bickford PC, Sanberg DC, Sanberg PR, et al. Cord blood rescues stroke-induced changes in splenocyte phenotype and function. Exp Neurol 2006; 199 : 191-200.

[42] Vendrame M, Gemma C, de Mesquita D, Collier L, Bickford PC, Sanberg CD, et al. Anti-inflammatory effects of human cord blood cells in a rat model of stroke. Stem Cells Dev 2005; : 595-604.

[43] Harris DT, He H, Gaballa M. The potential of cord blood stem cells for use in regenerative medicine of the heart. 2nd International Stem Cells Meeting, San Francisco, CA, 22-24 January 2007.
[44] Taguchi A, Soma T, Tanaka H, Kanda T, Nishimura H, Yoshikawa $\mathrm{H}$, et al. Administration of CD34+ cells after stroke enhances neurogenesis via angiogenesis in a mouse model. J Clin Invest 2004; 114 : 330-8.

[45] Harris DT, He X, Badowski M, Nicols JC. Regenerative Medicine of the eye: a Short review. In: Levicar N, Habib NA, Dimarakis I, Gordon MY, editors. Stem cell repair \& regeneration, vol. 3. London: Imperial College Press; 2008. p. 211-25.

[46]Brunstein CG, Setubal DC, Wagner JE. Expanding the role of umbilical cord blood transplantation. $\mathrm{Br} J$ Haematol 2007; 137: 20-35.

[47] Peled T, Mandel J, Goudsmid RN, Landor C, Hasson N, Harati D, et al. Pre-clinical development of cord bloodderived progenitor cell graft expanded ex vivo with cytokines and the polyamine copper chelator tetraethylenepentamine. Cytotherapy 2004; $6: 344-55$.

[48] Deutsch V, Hubel E, Kay S, Ohayon T, Katz BZ, Many $\mathrm{A}$, et al. Mimicking the haematopoietic niche microenvironment provides a novel strategy for expansion of haematopoietic and megakaryocyteprogenitor cells from cord blood. Br J Haematol 2010; $149: 137-49$.

[49] Delaney C, Heimfeld S, Brashem-Stein C, Voorhies H, Manger RL, Bernstein ID. Notch-mediated expansion of human cord blood progenitor cells capable of rapid myeloid reconstitution. Nat Med 2010; 16 : 232-6. 